\title{
The Red Oak Chautauqua Pavilion
}

Ralph Spencer

The information related in the following short article came primarily from Mr. Spencer's personal knowledge of the Chautauqua Pavilion in Red Oak (Montgomery County). He was born at Red Oak in 1897 and has lived through the period when Chautauqua flourished in the Middle West. Iowa was one of the first states to welcome and adopt the Chautauqua movement. Originally intended as a means of bringing better education to Sunday school teachers and people otherwise denied the privilege, its programs were broadencd to include concerts, lectures and readings. Before the days of rapid transportation, radio, television and movies, Chautauqua provided Iowans with an unparalleled Summer social event and educational experience. Today, the Pavilion in Red Oak, which once was the center of such activities, is on the National Register of Historic Places.-Ed.

IT MIGHT BE SAID that the cultural shot that "was heard around the world" was fired at Lake Chautauqua, New York in August of $1874 .{ }^{1}$ It was on this date that two public-minded citizens, John Vincent and Lewis Miller, set up the Methodist Sunday School Teachers Assembly to meet on the shore of beautiful Lake Chautauqua. It was designed to fill the demand for summer rest by uniting daily study and healthful recreation. The project was so successful that other denominations joined the Assembly, and popular lectures, concerts, readings and social entertainment were added. By 1886 about fifty Chautauqua groups were scattered throughout the country, and, as a recent

"Jeffrey Simpson, "Utopia by the Lake," American Heritage (August, 1972) XXIII, 5, 76-88. 
commentator noted, "the travelling Chautauquas, like the original, became organs of communication. Anything said at Chautauqua was sure to be heard-all over the Midwest, at least."

In the early part of the Twentieth Century the vast Middle West was hungry for culture. Only those who lived in the larger cities had access to opera, drama, musical concerts, poetry readings, and other cultural activities. Chautauqua filled a need for programs of this kind, and it was not long before it was flourishing in the prairie states.

A group of Red Oak citizens were quick to realize the potential of Chautauqua for their own community. Under the leadership of a United Presbyterian minister, the Rev. William Murchie, a committee was formed in Red Oak and talent was chosen. As a result, the first Chautauqua was held in Red Oak from June 29th to July 5th, 1905. A tent was set up in the Montgomery County Fair grounds that could accommodate about 3,000 people. Single admissions were 35 and a season ticket sold for $\$ 3.50$. Camping space was available on the grounds, and many people rented tents and camp furniture and spent the entire time on the grounds. Tents rented for about $\$ 3$ or slightly more, according to their size. There was a large dining tent and various churches took turns providing sumptuous dinners and suppers for a very nominal price. A place was also provided for those who drove horses where the teams could be fed, watered and sheltered. Popcorn, peanuts, and cracker jacks sold for $5 \dot{\xi}$ per sack or package, and lemonade for $5 \phi$ a glass.

An effort was made to bring people the best in music, lectures and entertainment of all kinds. The sessions began at nine o'clock in the morning with a children's hour. This was for all the young of the area and was guided by adult leaders provided by the Chautauqua talent. The last day of the session these young folks put on a special program of their own. At two in the afternoon a musical prelude was given and at two-thirty the main program was presented. This might be

${ }^{2}$ Ibid, 86; John Tebbel, "Chautauqua: A Nostalgic Salute," Saturday Review, January 11, 1969, 122-123. 


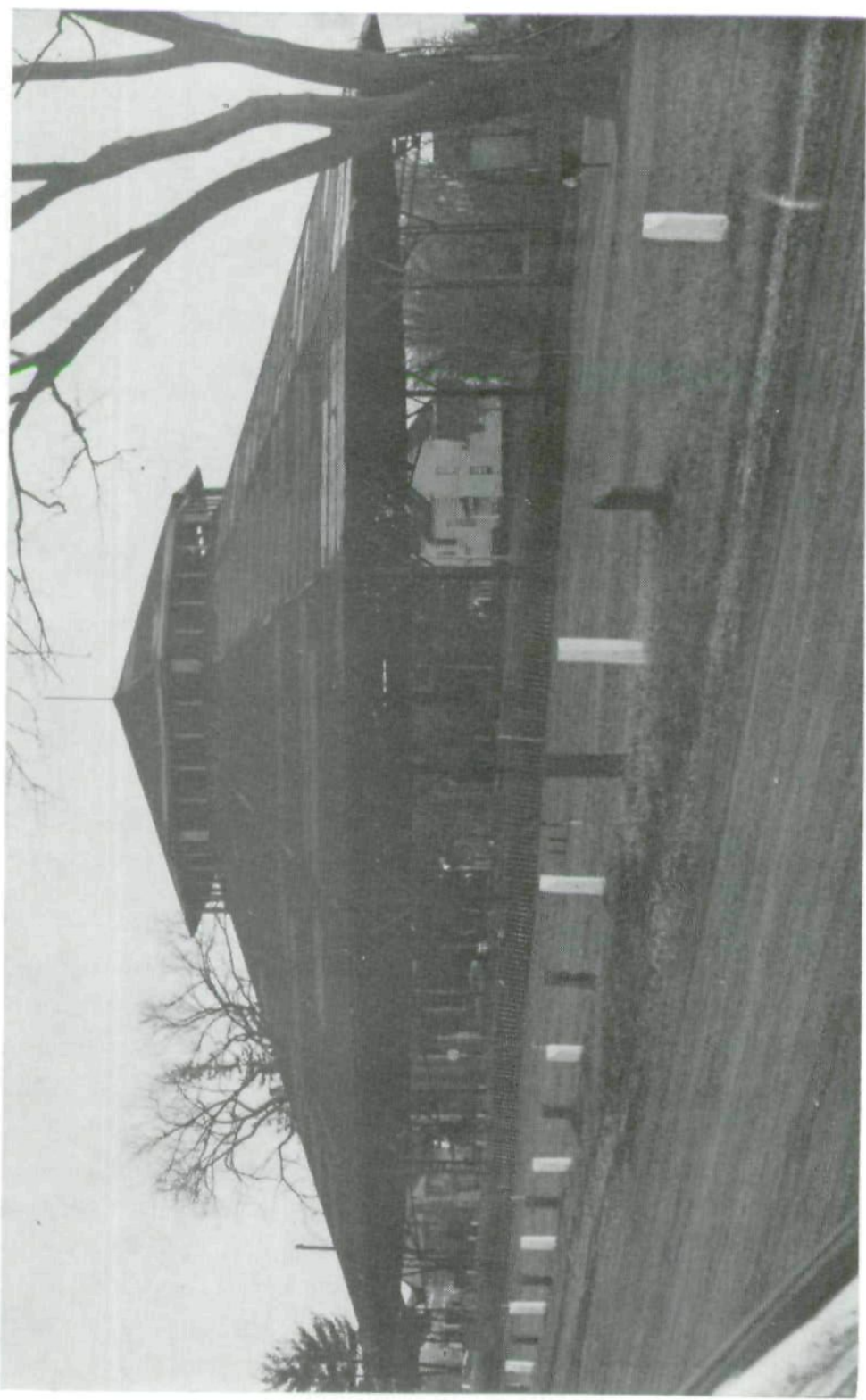

Courtesy of Travis Tinsley, Cbairman of Chautanqua Pavilion Restoration Committee

Red Oak Chautauqua Pavilion 
a lecture by some prominent man or woman, a band or orchestra, or a humorous speaker or group. During the years that Chautauqua flourished in Red Oak, practically all of the prominent talent in the country appeared on the platform at one time or another. Irvin S. Cobb, William Jennings Bryan, Robert LaFollett, Jane Adams, Billie Sunday and scores of others of equal note were present. The musical entertainment usually took place in the evening, and this also was preceded by a half hour prelude. Many of the great opera stars of the time were there. Big name bands and orchestras and groups of Negro singers were presented. Most every session featured a Negro quartet composed of men who sang spirituals and gospel hymns. Quite often an operatic number was presented. When it came time for the "Anvil Chorus," the lights were dimmed and as the hammers beat on the anvils, the sparks would fly, producing a very spectacular effect. Krylls Band and Innes Band often treated the audiences to programs of this kind.

Rains and wind storms plagued the Chautauqua and often the grounds became quagmires of mud. The tents had a way of leaking on the audience, but the crowds kept coming. Chautauqua audiences were a hardy lot and did not ordinarily let these little discomforts spoil their enjoyment. However, in 1907 the tent collapsed during a storm and a pole fell and seriously injured a person in the audience. It was at this point that the Chautauqua Association realized they needed a more stable and permanent home. No Federal grants were expected, or asked for, to cover the expense that construction of a permanent structure entailed.

The people of Red Oak buckled down and raised the necessary money themselves. A beautiful hillside site was purchased for $\$ 750$ and a pavilion of steel construction was erected at a cost of $\$ 5,200$. The seating capacity was about 4,500 , and many times all the seats were full, in which case people often sat on blankets and camp chairs around the outside. How could they all hear? We wonder-but they did. This was before the days of microphones and other electronic aids. Some of the speakers and lecturers talked for two to two and a half hours, projecting their voices so that all could 
enjoy their remarks. The only help they had was a copious supply of ice water and a vast amount of enthusiasm.

There were a number of companies that made a business of setting up programs for the smaller towns. RedpathVawter was one of these. They took care of all the details and the local committee had only to see to the ticket sales. This was not always the best system because one had to be satisfied with the programs provided by the company, which often failed to appeal to a particular town. Red Oak, as a result, chose to become an "independent" and book all of its own talent through agencies in Chicago and New York.

This worked out very well as they had on their programs people and organizations that seemed to fit their particular tastes. The pavilion was built on the western slope of a hill that overlooked the town and the rolling farm country beyond. It was a stimulating experience to view this lovely landscape, and many of our visiting speakers remarked on it. It was the custom to entertain some of the speakers, or other talent, in homes of local citizens while they were in Red Oak. Many friendships were developed in this way that lasted down through the years. Our Chautauqua sessions usually took place in late August. That seemed to be the season when most people could attend without too much interruption to their regular activities. Many evenings were cold and large canvases were stretched along the north sides of the pavilion to keep out the cool winds. On days when the program was of special interest, the stores of Red Oak closed so that everyone had the opportunity to attend. This fine entertainment flourished until the early 1930s. The advent of the radio, autos and hard surface roads spelled the end of Chautauqua.

And so an era ended. To many it seemed a pity. It was the one chance for country people to mingle and visit with their friends in town. Picnic suppers were shared before the evening entertainment began. It was a typical "Town Hall" atmosphere, where many questions of political, philosophical and social significance were discussed.

For the past ten or fifteen years the pavilion has stood in silent dignity. The ravages of time marred its appearance, 
but gradually it came to the people of Red Oak that they had in this building a valuable piece of memorabilia. It was typical "Chautauqua" and one of the very few remaining in the United States. Red Oak is a community that takes pride in its heritage. In 1969, a group obtained estimates of the cost of renovation and restoration, and subsequently made a city-wide appeal for the necessary funds. This was not too successful. In 1970 there was renewed interest, and a committee was appointed to look into all aspects of the situation. Sketches were drawn and a fund was established. All interested citizens were invited to contribute toward the cost of restoration. A survey was conducted for the future use of the pavilion for the enjoyment of the entire community. Many, many suggestions were made from a cultural standpoint, educational, recreational and others. Under the leadership of a local businessman, Travis Tinsley, a renewed enthusiasm was generated and progress accomplished. The Iowa State Review Committee has recently approved the Pavilion as a State Historical Site and it has been nominated and accepted for the National Register of Historical Places. Interested citizens and organizations have donated funds generously, and there is every indication that the Chautauqua Pavilion at Red Oak will soon be restored to its original state. It is hoped that it will once again provide a common meeting ground for the good people of Montgomery County. 
Copyright of Annals of Iowa is the property of State of Iowa, by \& through the State Historical Society of Iowa and its content may not be copied or emailed to multiple sites or posted to a listserv without the copyright holder's express written permission. However, users may print, download, or email articles for individual use. 